\title{
EXPERIMENTS WITH SMALL SIZE SHAPED CHARGES
}

\section{KISMÉRETÜ KUMULATÍV ROBBANÓTESTTEL VÉGZETT KISÉRLETEK}

\author{
KUGYELA Lóránd \\ (ORCID: 0000-0002-2869-8864) \\ kugyela.Iorand@gmail.com
}

\begin{abstract}
This paper describes the research on testing of small size point focal shaped charges. They were manufactured from composite- $B$, Semtex and pressed RDX, and binary explosives. As the liner and the whole structure of the charges were identical the mild steel penetration test was a clear method for comparing and quantifying their performance. The target setup was also standardized with different steel discs. During testing I realized that it was a practical development tool, to find a proper mixture for binary explosives. Since most of the shaped charge literature related to their evaluation, I wanted to have a simple, yet productive performance testing method that suited more to practical field works.
\end{abstract}

Keywords: melt cast explosives, shaped charge, penetration test, binary explosives

\begin{abstract}
Absztrakt
Jelen cikkben a kisméretü kumulatív töltetekhez kapcsolódó vizsgálataimról írok. A kísérletekhez: bináris, préselt hexogén, Semtex és Kompozit-B robbanóanyagokat használtam fel. Tekintve hogy szerkezetileg azonos kivitelezésü-kialakitásúak voltak, minden esetben azonos lágyvas korongokon történt az átütöképességük vizsgálata. A kísérletek során bebizonyosodott, hogy bináris robbanóanyagok fejlesztéséhez is jól alkalmazható módszert sikerült találni. végeredményként pedig egy olyan teljesítmény vizsgálatot szerettem volna kialakitani, ami illeszthető a gyakorlatias gyártási folyamatokhoz.
\end{abstract}

Kulcsszavak: öntött robbanóanyagok, kumulatív töltetek, átütés vizsgálat, bináris robbanóanyagok 


\section{INTRODUCTION}

In the past decade, an enormous amount of scientific research focused on the shaped charge phenomenon. [1] One common approach arises generally in them, the authors own way of thinking, to underpin the related existing thermodynamics and physics from their own point of view [2].

The idea to use the shaped charge mechanism [3] for testing explosives is not new. General question raised regarding to high explosives if they were suitable for different shaped charge application.

Conventionally, two categories can be drawn up regarding to the increase or modify the penetration abilities of shaped charge. The first one is the adjustment of the structural appearance, like the liner material, the cone angle, the standoff distance, the wave shaping, the initiation, the confinement etc. The second one relates strictly to the explosives, like the explosive properties, the loading density, etc. By changing any of the above-mentioned criteria significant changes may appear. [4] My procedure was to manufacture a standardized shaped charge structure, by which I can measure different explosive compositions penetration performance and use this approach as a brisance predicting method. For the jet formation some explosive properties have great importance like the critical diameter, the detonation velocity, and density. These properties together are needed for an appropriate shaped charge.

Before the test, candidates were needed to establish a fundament for the investigation. For this purpose, two materials were chosen, one was a semi-finished product for high penetration capability $40 \mathrm{~mm}$ grenade, with pressed shaped charge, and another one was a commonly available plastic explosive. The focus of the trials was to build up a reproducible setup and then collect data to further development of binary explosives and other explosive mixtures penetration abilities. The approach of these tests are similar as in the STANAG 4526 [5].

\section{SET-UP}

The copper cone liners had $60^{\circ}$ of cone angle, and $1,5 \mathrm{~mm}$ of thickness. Their average weight was $13 \mathrm{~g}$.

With some technical help from a turner company a liner holder mounting was manufactured that served more purposes. Most importantly, it centralized a liner in an axis-symmetric position, acted as a standoff and a reversed of cone air cavity.

The tubing was an aluminium pipe that could be cut to predefined length. It holds the liner mounting at the bottom, and the detonator centralizer disc at the top.

Figure 1 shows the liner mounting cross-section. Figure 2 shows the shaped charge components. 


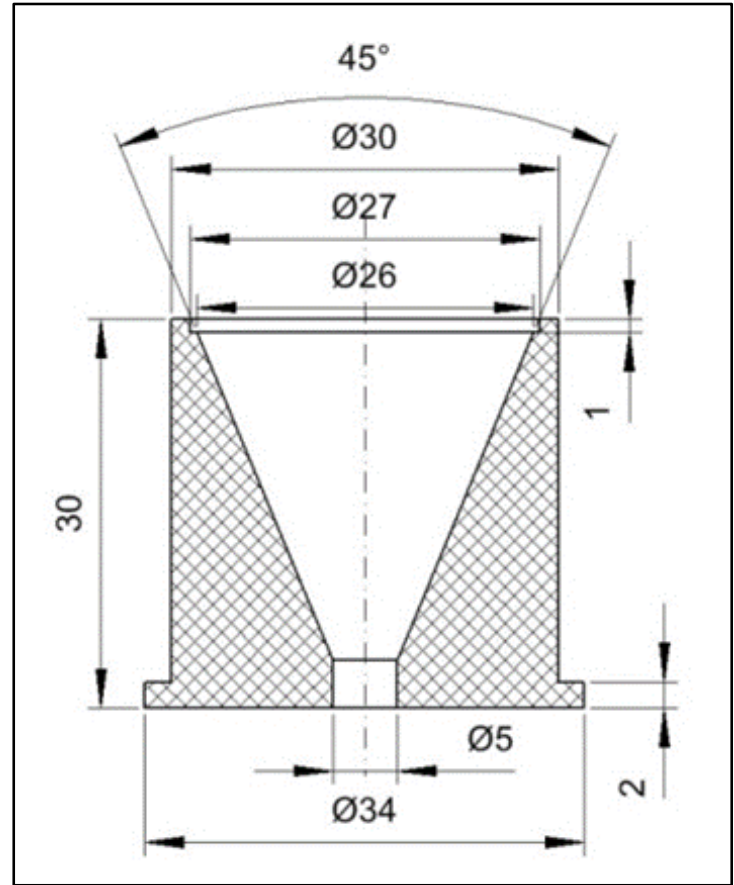

Figure 1: Liner mounting cross-section

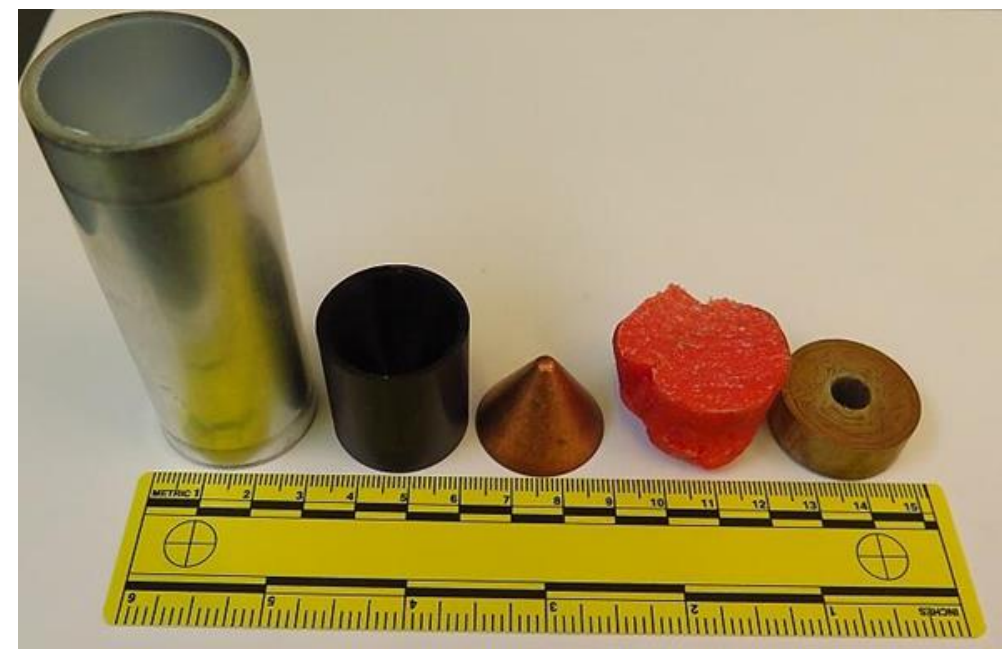

Figure 2: Shaped charge contents

The target assembly is a centralizing and clamping unit that holds the target mild steel discs tightly together and holds the shaped charge in the proper place. The two, separate central aligned fixtures hold the target assembly by three screws and a small ditch inside, while they pull and lock the discs together. This structure allows a fast, convenient way of testing as the settings can be varied quickly as different disc sequence can be adjusted. For example, if we predict that the penetration will be bigger than $50 \mathrm{~mm}$, first we place the $50 \mathrm{~mm}$ disc then $10 \mathrm{~mm}$ or $20 \mathrm{~mm}$. In case of smaller penetration thinner discs can placed under the charge. The setup eliminates the human-borne positioning errors. Due to the standoff distance the explosion does not damage the head part and up to now, the device withstands several dozens of blasts. 


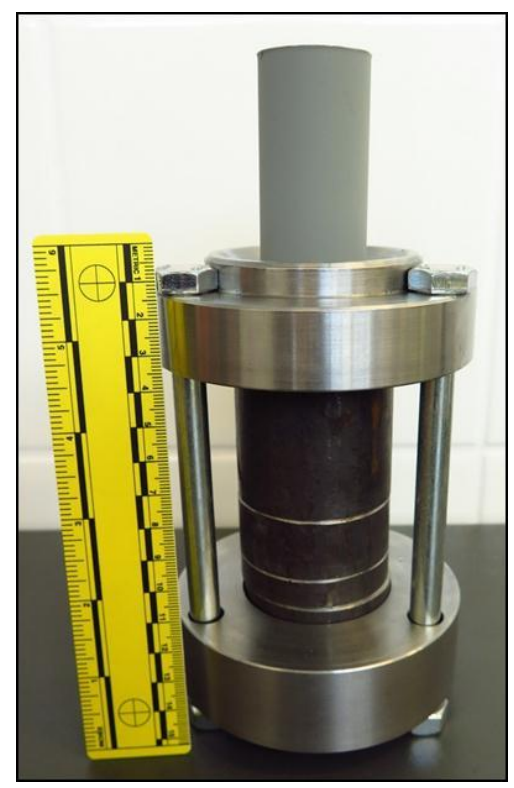

Figure 3: Target assembly with a shaped charge on the top

\section{Explosives for shaped charges}

Four different types of explosives were used to validate the idea.

Plastic explosives, such as Semtex 1A and Semtex PLHX30 are commonly available and exceptionally suitable for this task.

Pressed explosives as mentioned in the introduction this charge is an RDX containing semifinished product with high dimensional accuracy. Figure 4.

Melt cast material was the Comp-B (60/40). Manufacturing of the cast explosive itself was a challenging method, as the solidification, and the heat conduction problems of the small sizes and quantities $(\sim 22 \mathrm{~g}-46 \mathrm{~g})$ of materials can cause more significant discrepancies than in productions of several kilograms.

Binary explosive mixture was a classical nitro-paraffin / oxidizer mixture with and without atomized aluminum.

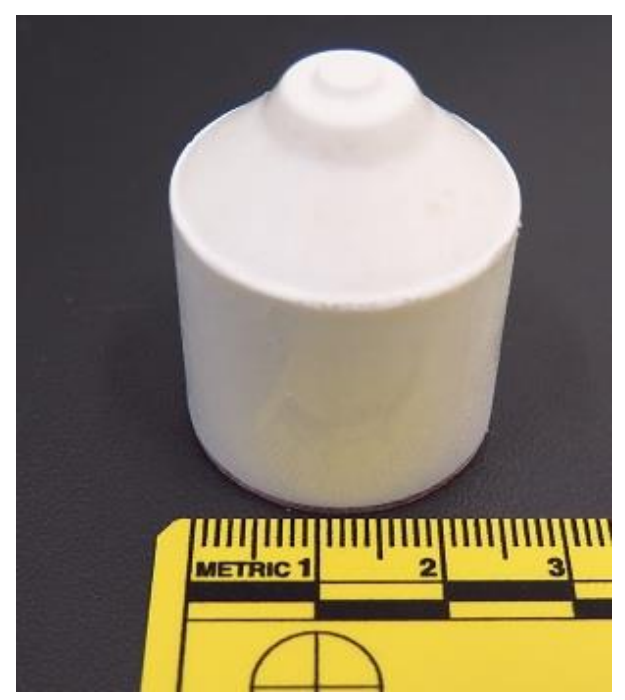

Figure 4: RDX shaped charge 


\section{TESTS}

During the experiment differently shaped charges were tested. Table 1 describes their type, weight and other necessary remarks.

\begin{tabular}{lll}
\hline Explosive & Weight $(\mathbf{g})$ & Remark \\
\hline Semtex 1A & 25 & without waveshaper \\
Semtex 1A & 25 & with waveshaper \\
Semtex PLHX 30 & 25 & $8 \%$ Al content \\
RDX & 14,3 & pressed \\
Comp-B & 25,1 & cast \\
Comp-B & 30,8 & cast \\
Comp-B & 46,1 & cast \\
Comp-B & 22,6 & cast \\
AnNmAl* & 50 & $2,5 \% \mathrm{Al}$ \\
AnNmAl & 25 & $2,5 \% \mathrm{Al}$ \\
AnNm & 50 & without Al \\
AnNm & 25 & without Al \\
$*$ AnNmAl: Ammonium-nitrate, nitromethane, aluminium mixture \\
\hline
\end{tabular}

Table 1. Summary table for the explosives in the experiments

First the plastic explosives were tested. During the experiments the collar diameter of the hole and the depth of penetration were measured.

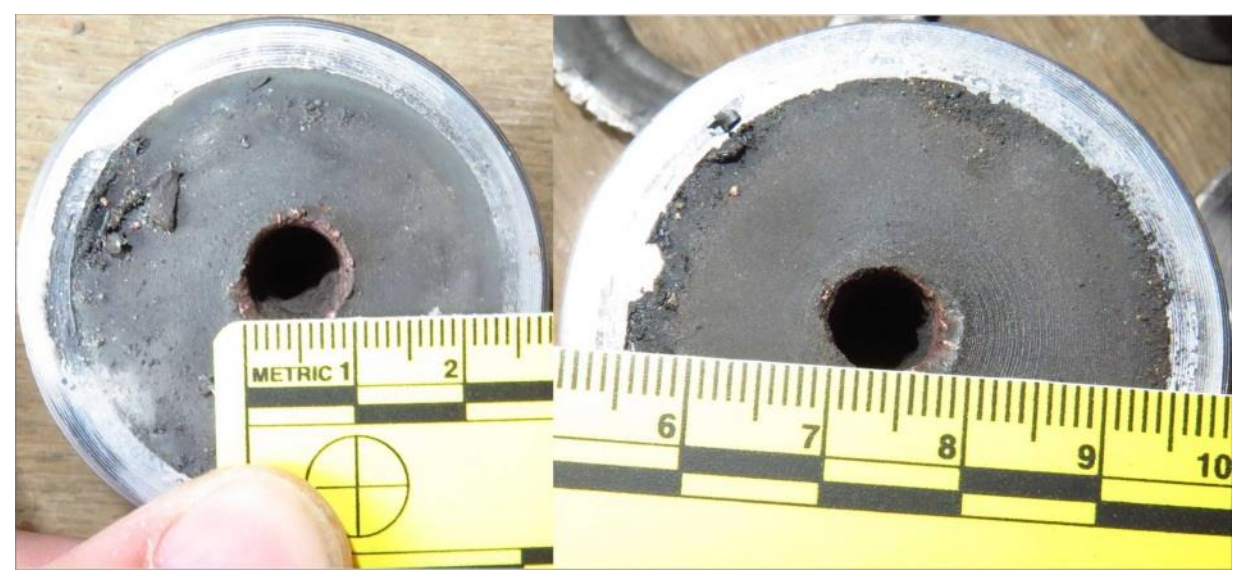

Figure 5: Result for Semtex 1A with (right), and without waveshaper (left)

The diameter decreased by $2 \mathrm{~mm}$ average in case of the waveshaper but the penetration increased from $46 \mathrm{~mm}$ to $51,6 \mathrm{~mm}$. For the Semtex PLHX30 the hole diameter was $9,1 \mathrm{~mm}$ and the length $51,5 \mathrm{~mm}$.

As the plastic explosives were exceptionally suitable for high performance shaped charges, the results of each case showed symmetry and repeatability. 


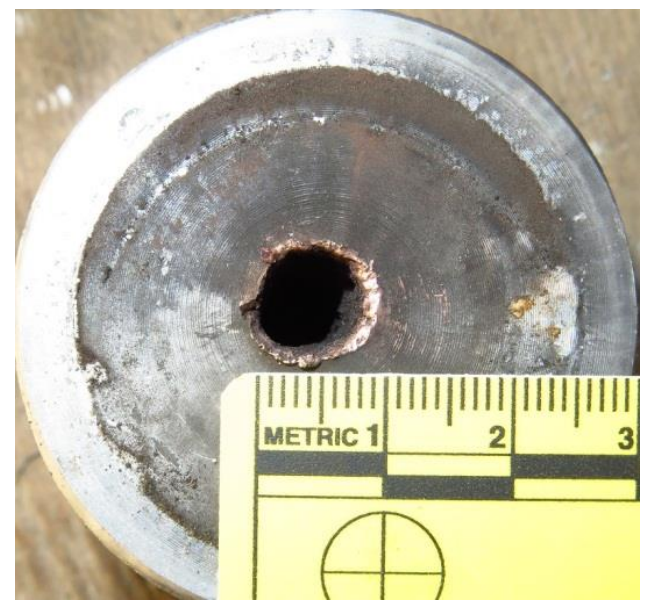

Figure 6: Result for Semtex PLHX30.

The RDX pressed charge showed some inconsistency which could be attributed to the pressing procedure. From each of the 3 blasts some amount of copper splatter remained on the surface of the discs. The average diameter at the collar was $7,3 \mathrm{~mm}$, and the length was $51 \mathrm{~mm}$.

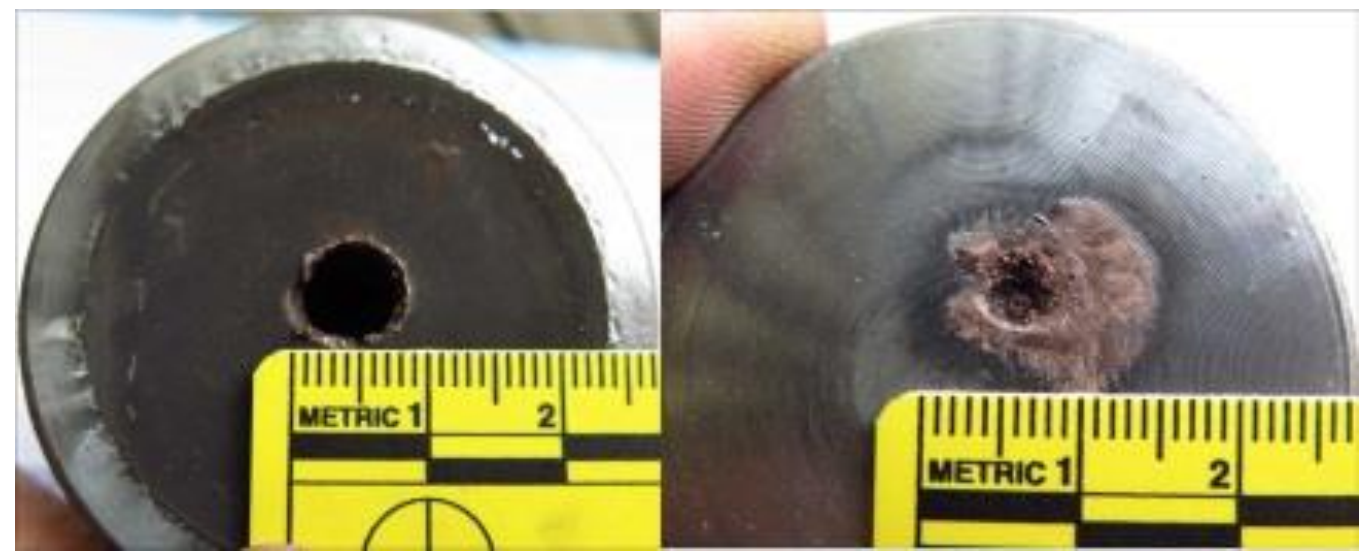

Figure 7: Pressed RDX charge entry (left), and the jet on the second disc (right).

Manufacturing of the melt cast composition in such small charges proved to be challenging. Melting the TNT and adding RDX happened in a Teflon coated pan with steam heating at $90^{\circ} \mathrm{C}$ $91^{\circ} \mathrm{C}$. Meanwhile, the shaped charge assembly was heated in a steam bath to avoid the instant solidification at the filling procedure. A vibration motor built into the mounting of the shaped charge, for eliminating the shrinking issues during the cooling phase. In theory, this seemed obvious, but in the practice, it was different. The vibration alone did not solve the solidification. The fill-up carried out in multiple steps. Between each step, the floating "plate" shattered then the next portion was poured immediately. With this procedure, the reducing volume filled up with molten material instead of air gap. Without continuous stirring the $4 \%$ wax content of the RDX accumulated at the top of the melted explosive mixture. As around 5 grams of RDX dissolved in $100 \mathrm{~g}$ TNT [6] the regular agitation was mandatory to avoid layering of the explosives. Without this action when the charged body was filled, different density and concentration explosive sections would be built up which could have raised the sensitivity of ignition. The RDX eutectic would place around the liner and at the top segment a TNT rich layer was built up with a wax layer on the surface.

For the performance test four composite-B charges were made. The weights of explosive were from $22,6 \mathrm{~g}$ to $46,1 \mathrm{~g}$. 


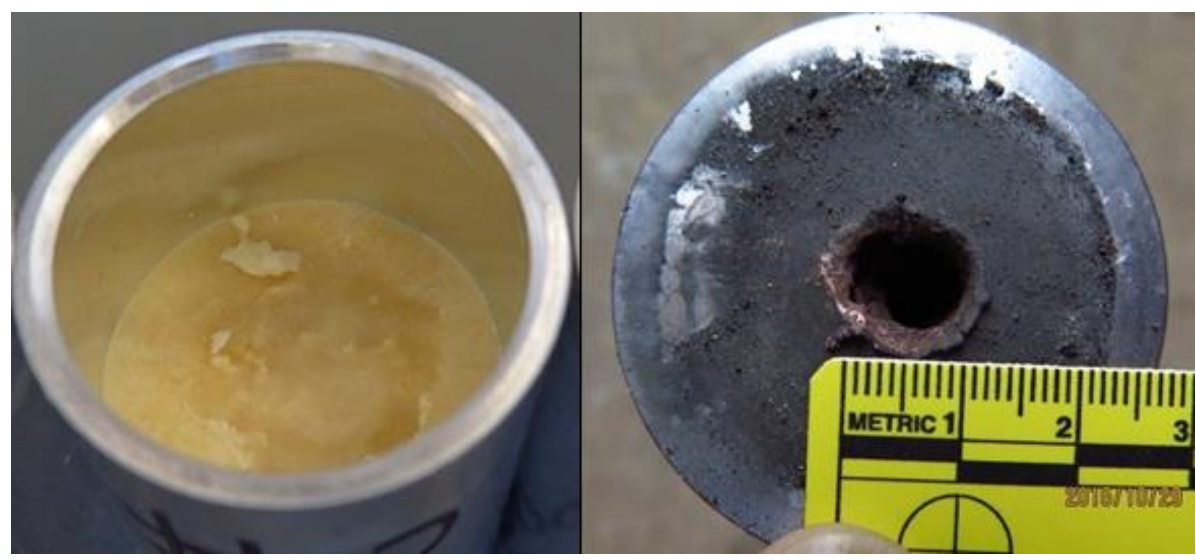

Figure 8: Result of 25,1g Composite-B.

This amount of composition barely covered the liner. The diameter was $9,4 \mathrm{~mm}$, the length was $32,3 \mathrm{~mm}$

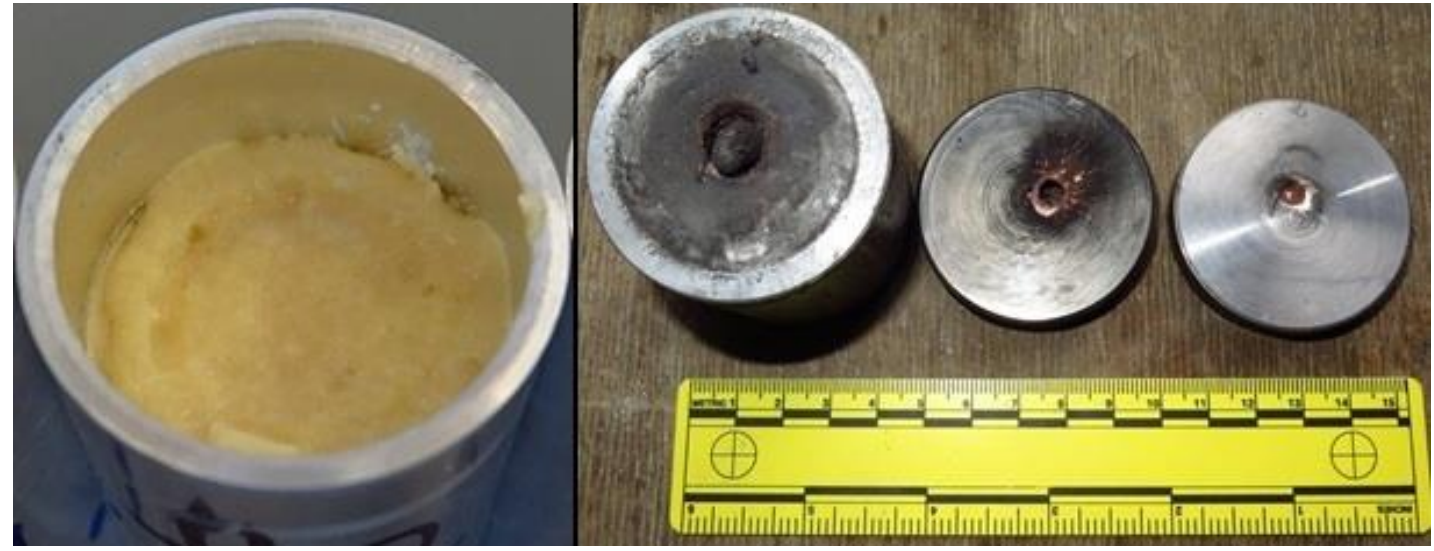

Figure 9: Result of 30,8 g Composite-B.

Although the slug remained at the collar point at the disc the penetration was almost the double as at the previous one. Diameter was $10 \mathrm{~mm}$ and the length was $61,5 \mathrm{~mm}$.

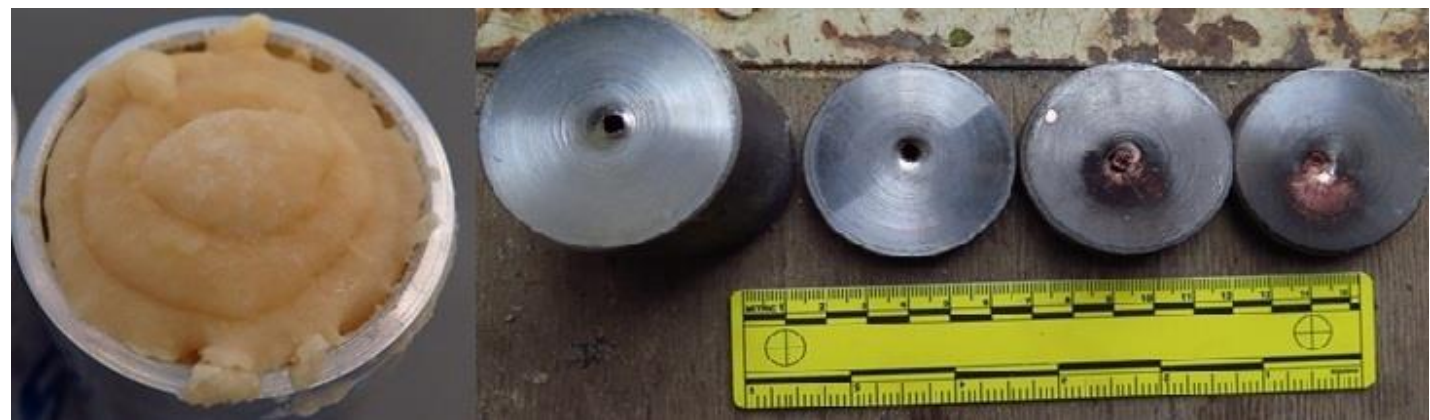

Figure 10: Result of 46,1 g Composite-B.

This shaped charge contained the largest amount of cast explosive and had a sizable penetration length of $71 \mathrm{~mm}$ and the diameter of $11,2 \mathrm{~mm}$. The Figure 10 shows the penetration through a $50 \mathrm{~mm}-10 \mathrm{~mm}-10 \mathrm{~mm}$ mild steel discs. 


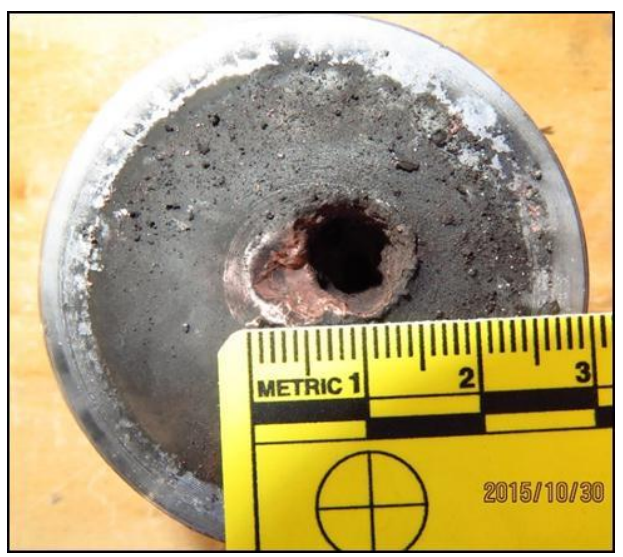

Figure 11: Result of 22,6 g Composite-B.

At this test, the effect of the asymmetrical jet formation can be seen. Presumably, the tail part (slug) came off and deformed the collar of the hole. The diameter was 9,2mm, the length was $31 \mathrm{~mm}$.

In case of binary explosives, classic nitroparaffin and ammonium-nitrate mixtures were used. Comparing this mixtures effectiveness to RDX or PETN containing explosives definite recession is perceptible, even so, the jet formation exists. All those materials which detonation properties highly dependent on the diameter and the confinement this test shows the correlation between this circumstance and their performance. The large fraction prill containing AnNm detonation has failed this partial detonation can be observed in Figure 12. The close up of recovered liner and their comparisons are on Figure 13.

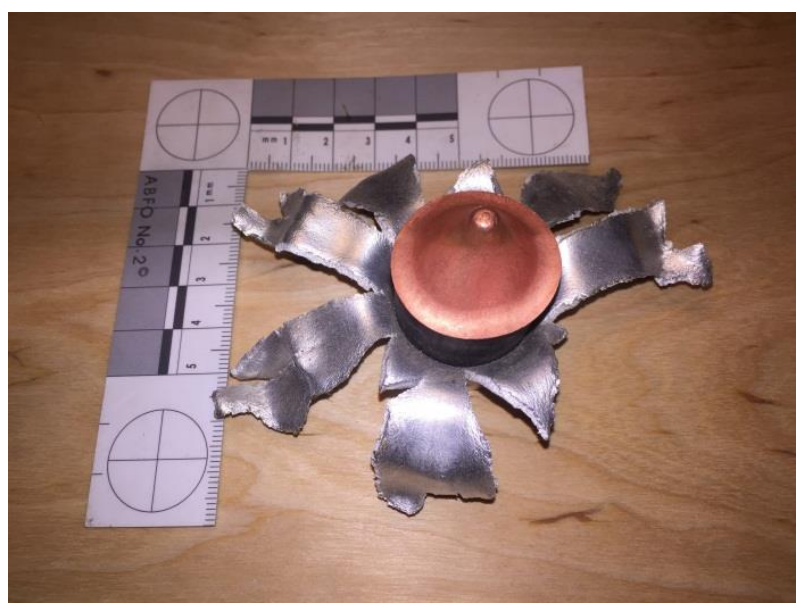

Figure 12: Result of 22,6 g Composite-B.

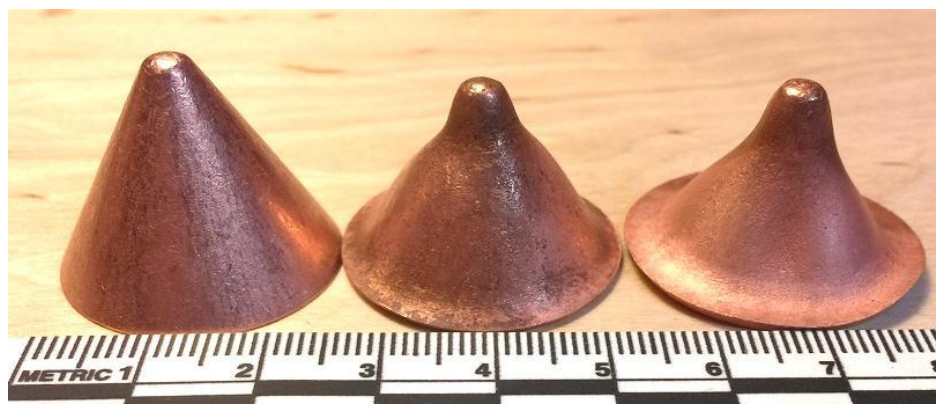

Figure 13: Intact (left) and deformed liners due to partial detonation (middle, right). 
The AnNm and AnNmAl compositions were tested in $50 \mathrm{~g}$ and $25 \mathrm{~g}$ trials to examine the penetration decrease due to the lower charge weight.

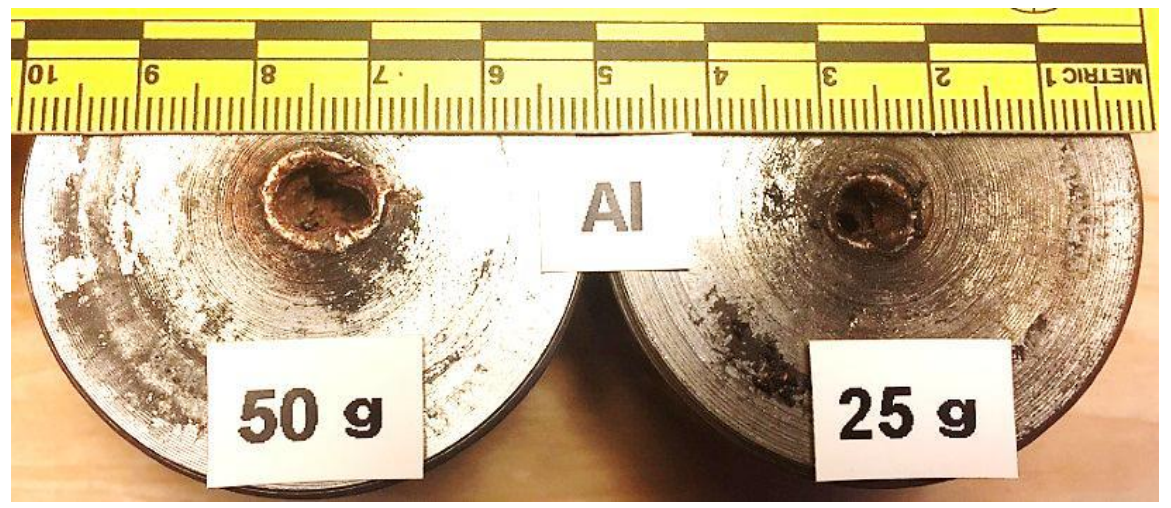

Figure 14: AnNmAl 50-25g targets

\section{JET VELOCITY TESTING EXPERIMENTS}

Beside the many factors which can modify the jet's penetration, one important value should also be mentioned. In the face of effectiveness, the jet tip velocity gives a good estimation how the shaped charge will perform. Needless to say that highest velocity values can be achieved with precision manufactured pressed charges, loaded with RDX, HMX, HNS [7].

The principal of the procedure is like the case of the detonation velocity (Vod) measurements [8] [9]. The testing unit is equipped with high resolution timer and it measures time between its probes and then calculates the speed of the detonation.

High-end equipment (high speed imaging) [10] can give more complex results from the jet formation, [11] however a less sophisticated set-up can also handle the measurement.

I choose the unit with break wire method. The calculation principle based on a time measuring between voltage-drops of electric probes. The probes in this case are thin copper cables.

The measurement setup built up from the following main parts:

- Explosive shaped charge

- Measurement cable assembly with positioning pipe

- Detonation time meter (resolution: $+/-0,1 \mu \mathrm{s}$ )

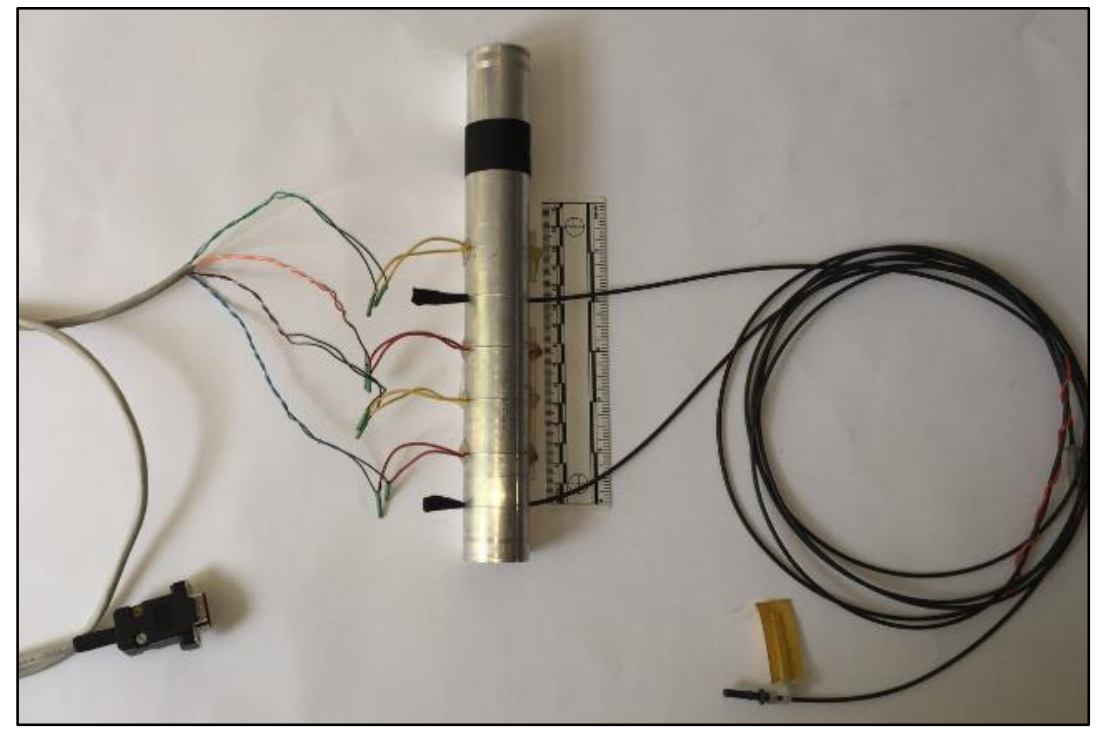

Figure 15: Jet velocity measurement setup with two different methods 
The difficulties with this method are the following:

- In case of asymmetrical jet forming, the jet tip does not cut the circuit wires, and it can lead no result.

- If the break wires are not axial with the jet tip, it can happen that the lower velocity jet body or the end slug will trigger the measurement. This can be testified if lower values appear.

- The optical and break wire method together is not reliable. The small copper particles ripped from the break wire can easily destroy the optical wire well before it is triggered by the light itself.

- In case of not precisely manufactured charges the probes may need to be within the range of the optimal standoff distance (SoD) as the splattering of the jet occurs in larger SoD, more unpredictable test results will appear.

The measurements were not carried out for each case, just in order to have comparable results between the RDX and the binary explosives, and to verify that this method is also suitable for such measurements. As I wrote in the preface, the "standard" charge was the RDX pressed charge, from a 40mm grenade.

\begin{tabular}{|c|c|c|c|c|c|}
\hline \multirow[b]{2}{*}{ Probes } & \multicolumn{2}{|c|}{ RDX pressed charge } & \multirow[b]{2}{*}{ Probes } & \multicolumn{2}{|c|}{ Binary explosive } \\
\hline & $\begin{array}{l}\text { Distance(m } \\
\text { m) }\end{array}$ & $\begin{array}{l}\text { Vod } \\
(\mathrm{m} / \mathrm{s})\end{array}$ & & \begin{tabular}{|l} 
Distance(m \\
m)
\end{tabular} & \begin{tabular}{|l} 
Vod \\
$(\mathbf{m} / \mathbf{s})$
\end{tabular} \\
\hline $\begin{array}{l}\text { BW0- } \\
\text { BW1* }\end{array}$ & 50 & 6493 & $\begin{array}{c}\mathrm{O} 1- \\
\mathrm{O} 2 * *\end{array}$ & 50 & 2475 \\
\hline $\begin{array}{l}\text { BW0- } \\
\text { BW2 }\end{array}$ & 75 & 6000 & $\mathrm{O} 2-\mathrm{O} 3$ & 50 & 2427 \\
\hline $\begin{array}{l}\text { BW0- } \\
\text { BW3 }\end{array}$ & 100 & 4149 & - & - & - \\
\hline $\begin{array}{l}*: " \mathrm{BW} \\
\text { **:"'O"' }\end{array}$ & $\begin{array}{l}\text { ponds for bre } \\
\text { oonds for opt }\end{array}$ & $\begin{array}{l}\text { wire me } \\
\text { method }\end{array}$ & & & \\
\hline
\end{tabular}

Table 2. Summary table for the explosives in the experiments

To verify the two methods, I conducted standard detonation velocity measuring test, in which both methods were done simultaneously, see Table 2 . The differences were within $1,9 \mu \mathrm{s}$ in $100 \mathrm{~m}$ distance which means $460 \mathrm{~m} / \mathrm{s}$ the highest. As the placing of both probe types are critical in the result's point of view, I consider this measuring method also suitable for such jet velocity measurements.

\section{RESULTS}

The complete results can be found in Table 3. The performance row comes from the multiplication of the holes collar diameter by its length that serves as a ratio of the penetration. Performance by weight results from the division of the mentioned ratio by the explosive weight. With this method a sequence that correlates to the theoretical approach of the brisance of the used explosives can be set.

The jet velocity measurements both with optical and break wire method, can be a good additional low-cost method for evaluating the performance of shaped charges. The results for the RDX pressed charge are within the values stated by the manufacturer. For the binary charges further tests need to be performed, but the test results are in line with the difference shown in their penetration ability. 
$\underline{\text { KUGYELA: Experiments with small size shaped charges }}$

\begin{tabular}{|c|c|c|c|c|c|c|}
\hline Explosive & $\mathrm{m}(\mathrm{g})$ & $\begin{array}{c}\mathrm{d} \\
(\mathrm{mm})\end{array}$ & $\begin{array}{c}1 \\
(\mathrm{~mm})\end{array}$ & $\begin{array}{c}\text { Performan } \\
\mathrm{ce}\end{array}$ & $\begin{array}{c}\text { Perfor } \\
\text { mance by } \\
\text { weight }\end{array}$ & $\begin{array}{c}\text { Remar } \\
\mathrm{k}\end{array}$ \\
\hline RDX & 14,3 & 7,3 & 51 & 372,3 & 26,03 & $\begin{array}{c}\text { presse } \\
\mathrm{d}\end{array}$ \\
\hline $\begin{array}{c}\text { Semtex } \\
\text { PLHX 30 }\end{array}$ & 25 & 9,1 & 51,5 & 468,6 & 18,75 & $\begin{array}{c}8 \% \mathrm{Al} \\
\text { content }\end{array}$ \\
\hline Semtex 1A & 25 & 9 & 46 & 414 & 16,56 & - \\
\hline Semtex 1A & 25 & 7 & 51,6 & 361,2 & 14,45 & $\begin{array}{c}\text { waveshape } \\
\text { r }\end{array}$ \\
\hline Comp-B_\#2 & 30,8 & 10 & 61,5 & 615 & 19,93 & cast \\
\hline Comp-B_\#6 & 46,1 & 11,2 & 72 & 810,7 & 17,59 & cast \\
\hline Comp-B_\#4 & 22,6 & 9,2 & 31 & 285,2 & 12,62 & cast \\
\hline Comp-B_\#3 & 25,1 & 9,4 & 32,3 & 303,6 & 12,10 & cast \\
\hline AnNmAl_50 & 50 & 6,1 & 34,7 & 211,6 & 4,23 & $\begin{array}{c}2,5 \% \\
\text { Al }\end{array}$ \\
\hline AnNmAl_25 & 25 & 5,7 & 24,7 & 142,7 & 5,71 & $\begin{array}{c}2,5 \% \\
\text { Al }\end{array}$ \\
\hline AnNm_50 & 50 & 5,6 & 30,5 & 170,8 & 3,42 & - \\
\hline AnNm_25 & 25 & 4,7 & 19,5 & 93,2 & 3,73 & - \\
\hline m=explosiveweight; $d=h o l e$ diameter; l=hole length & & & \\
\hline
\end{tabular}

Table 3. Complete test results

\section{RESULTS}

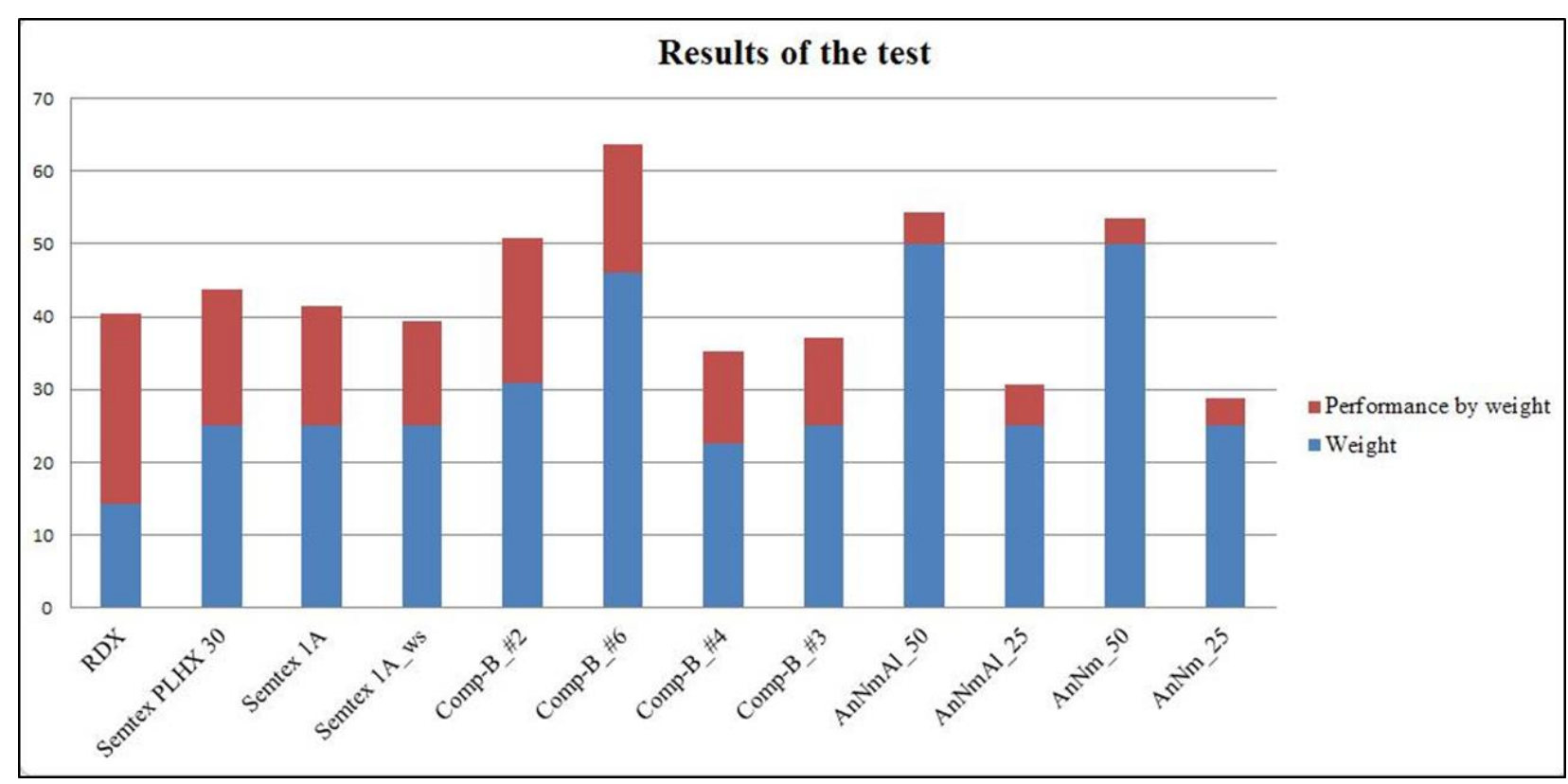

Figure 16: Results in graph format

Figure 16 contains all the measured values organized in bar graphs. Each bar corresponds one explosive, of which the lower blue part is the weight, and the upper is the performance by weight. Figures confirm the theory that explosives with higher detonation velocity (RDX, PETN) also have higher energy content per mass. In case of melt cast explosives, it shows that 
even it contains hexogen the melting procedure have complex effects on penetration. In case of binary explosives, the jet forms properly what correlates to a stable and higher detonation velocity, however, due to the lower density the penetration stays at a lower level.

The motivation for undertaking this study was to compare different kind of explosives concerning their detonation properties and to find the correlation between their penetration abilities. In case of developing new compositions or just verifying the adequate amount of energizers in the explosive, this practical method can be applied. From the theoretical point of view, their capabilities are predictable however not quantified.

With this method, different explosive mixtures can be tested for shaped charges because both, the jet formation and the proper detonation run up should be present. The composition has to detonate in small quantities and relatively small diameter in order to create an appropriate jet.

From practical point of view, it is a small-scale test that can perform with grams instead of kilograms of materials. It can be accomplished in blasting chambers because does not required specific instruments.

It is a suitable method for development, or other cases when the reasonable comparability and repeatability are important factors.

\section{REFERENCES}

[1] WALTERS, W.P.;ZUKAS, J. A.: Fundamentals of shaped Charges. Wiley, 1989

[2] J. BROWN, I.D. SOFTLEY, and P. EDWARDS: Experimental Study of Shaped Charges with Built-in Asymmetries, Propellants, Explosives, Pyrotechnics 18, pp. 255-258, 1993

[3] K. H. KAMARUdin, A. M. A. ZAIDI, S. ABDUllaH \& Md F. S. KOSLAN: Establishment of Shaped Charge Optimum Parameters for Small Scale Hydrodynamic Penetration, Modern Applied Science, Vol. 10, No. 1; pp. 82-92, 2016.

[4] V.BOHANEK, M. DOBRILOVIC, V.SKRLEC: The efficiency of linear shaped charges, Tehnicki vjesnik 21, 3 pp. 525-531, 2014

[5] E. L. BAKERA, J. PHAMA, T. MADSENA, W. POULOSA and B. E. FUCHSA: Shaped Charge Jet Characterization and Initiation Test Configuration for IM Threat Testing, Procedia Engineering 58, pp. 58-67, 2013

[6] TM 9-1300-214 Military Explosives, Department of Army Technical Manual, p. 119 1984.

[7] E. ZVONIMIR, M. DOBRILOVIĆ, B. JANKOVIĆ, Z TOMIČIĆ, M. ODAK: Jet velocity and the effects of the shaped charge perforator for use in the oil and gas well, International Seminar; 9th, New trends in research of energetic materials; (NTREM), Pardubice, pp.581-586, 2006

[8] EN 13631-14; Explosives for civil uses, High explosives, Part 14: Determination of velocity of detonation. 2003

[9] Dr. A. von OERTZEN: Demonstration of Proficiency by Round-Robin Tests among explosives Notified Bodies, EFEE, 7th World Conference on Explosives \& Blasting, Moscow, ISBN 978-5-98746-0160-0, pp. 78-81, 2013

[10] M. S. SHATTUCK: Determination of detonation velocity of explosive compounds using optical techniques, New Mexico Institute of Mining and Technology, 2015

[11] S.G.TATAKE, D.K.KHARAT, Flash X-ray: A diagnostic tool for shaped charge studies. Defence Science Journal, Vol.42, No.4. pp 259-264, 1992, 